
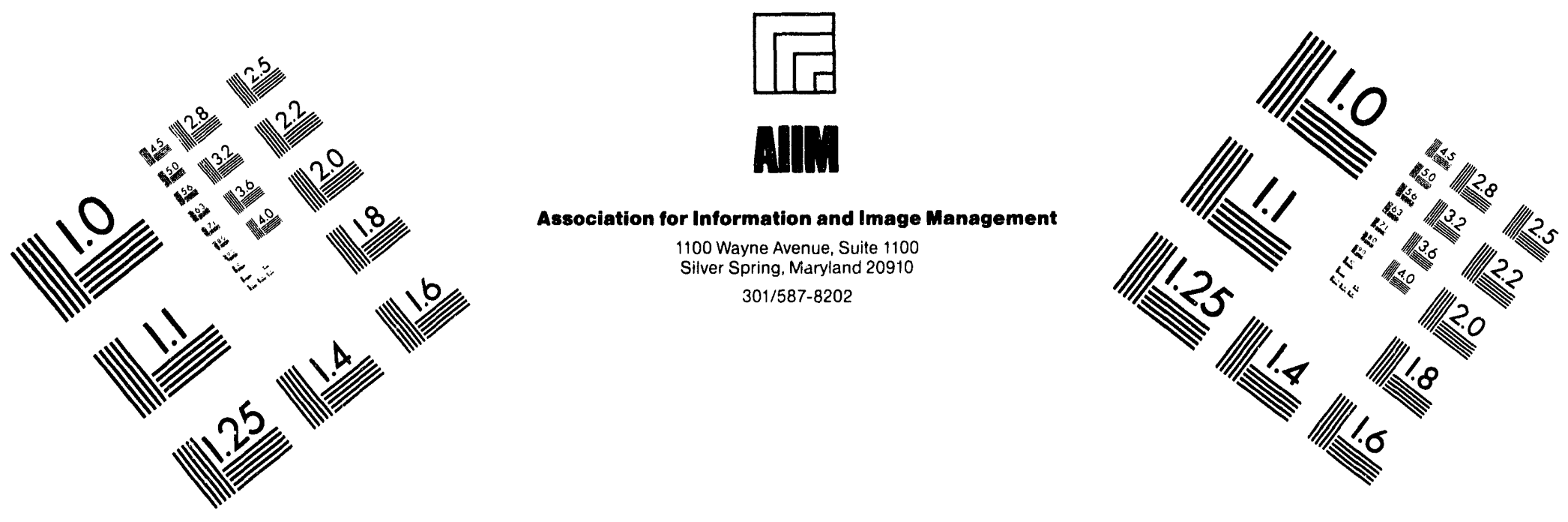

Centimeter

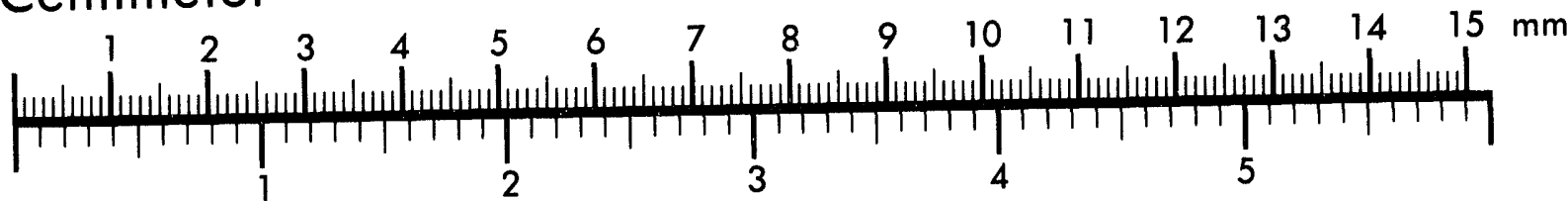

Inches
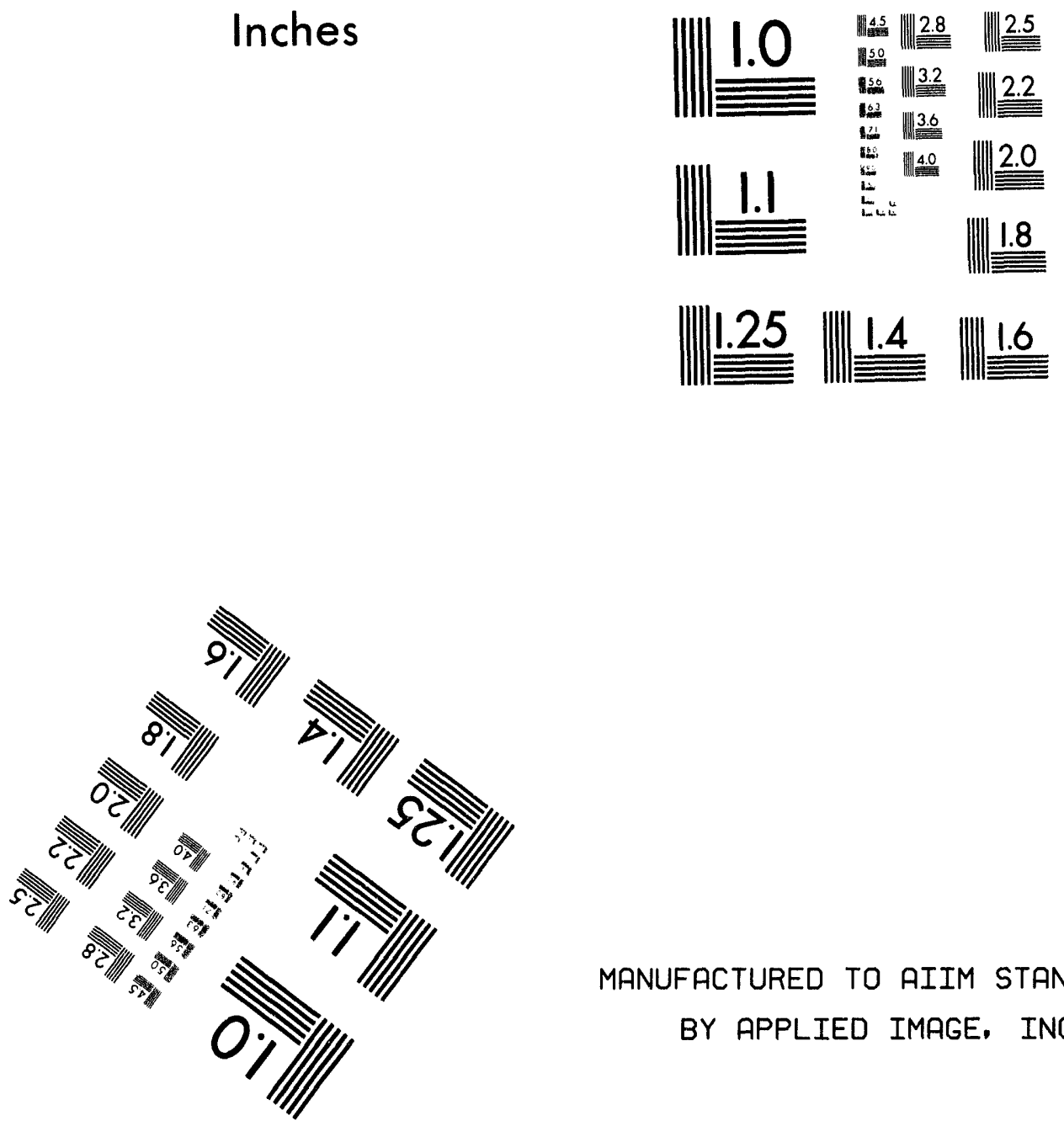

MANUFACTURED TO AIIM STANDARDS

BY APPLIED IMAGE, INC.

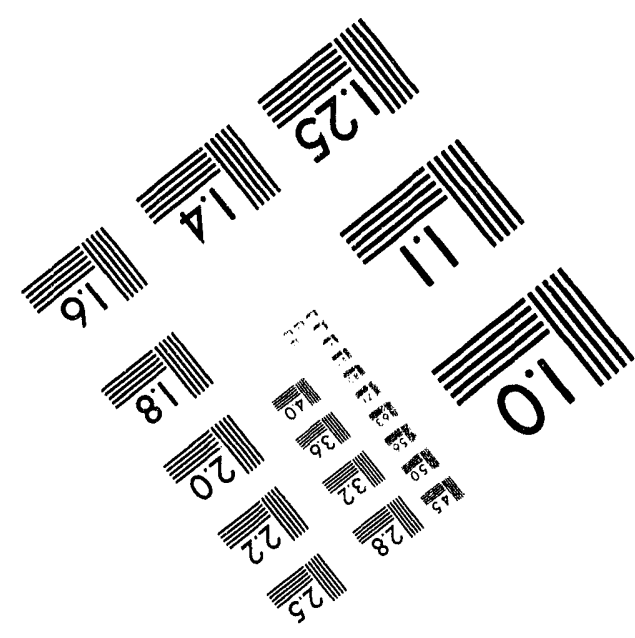



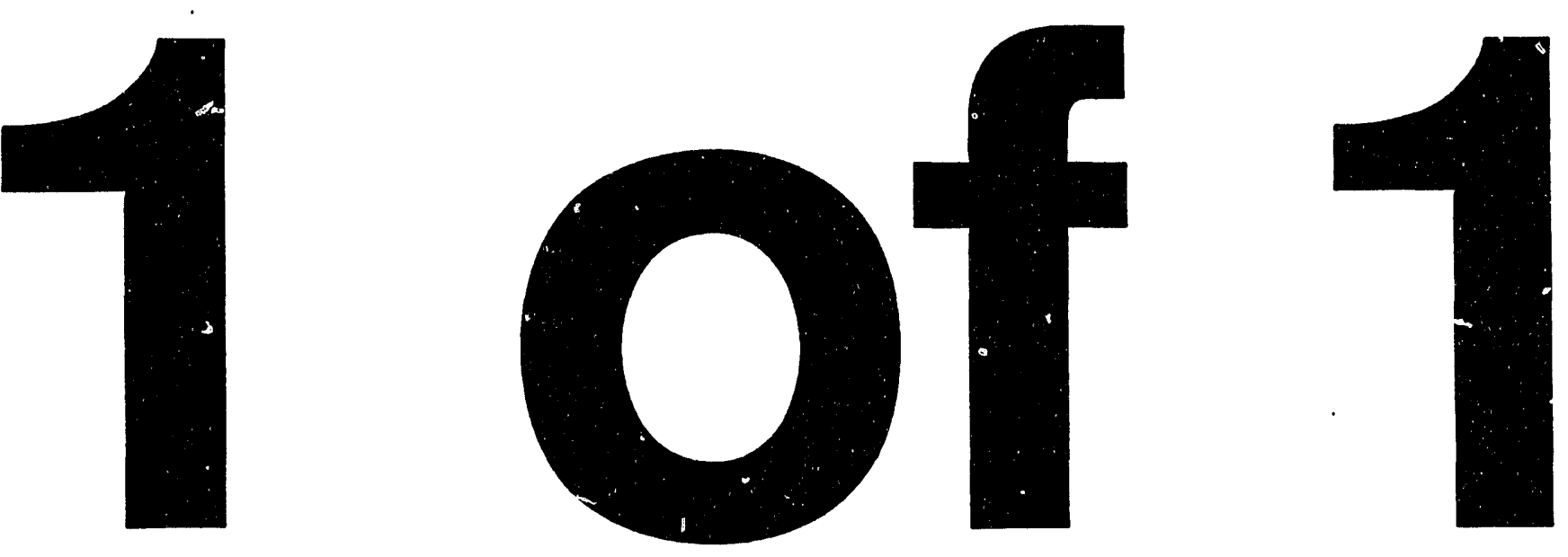


\section{TRANSURANIC RADIONUCLIDES FROM RESUSPENSION IN THE ENVIRONMENT, A BIBLIOGRAPHY}
A. Carol Stoker
Joseph H. Shinn
Victor E. Noshkin
Kai M. Wong
James L. Brunk
Cynthia L. Conrado
Henry E. Jones
Steven Kehl
Marshall L. Stuart
Liena M. Wesley
Rayla V. Bradsher
William L. Robison

April 1994

This is an informal report intended primarily for internal or limited external distribut: 3 . The opinions and conclusions stated are those of the author and may or ma; not be thos: of the Laboratorv. 
This document was prepared as an acccount of work sponsored by an agency of the United States Government. Neither the United States Government nor the University of California nor any of their employees, makes any warranty, express or implied, or assumes any legal liability or responsibility for the accuracy, completeness, or usefulness of any information, apparatus, product, or process disclosed, or represents that its use would not infringe privately own rights. Reference herein to any specific commercial products, process, or service by trade name, trademark, manufacturer, or otherwise, does not necessarily constitute or imply its endorsement, recommendation, or favoring by the United States Government or the University of California. The views and opinions of authors expressed herein do not necessarily state or reflect those of the United States Government or the University of California, and shall not be used for advertising or product endorsement purposes.

This report has been reproduced directly from the best available copy.

Available to DOE and DOE contractors from the Office of Scientific and Technical Information

P.O. Box 62, Oak Ridge, TN 37831

Prices available from (615) 576-8401, FTS 626-8401

Available to the public from the

National Technical Information Service

U.S. Department of Commerce

5285 Port Royal Rd.,

Springfield, VA 22161 


\title{
TRANSURANIC RADIONUCLIDES FROM RESUSPENSION IN THE ENVIRONMENT, A BIBLIOGRAPHY
}

\author{
A. Carol Stoker \\ Joseph H. Shinn \\ Victor E. Noshkin \\ Kai M. Wong \\ James L. Brunk \\ Cynthia L. Conrado \\ Henry E. Jones \\ Steven Kehl \\ Marshall L. Stuart \\ Liena M. Wasley \\ Rayla V. Bradsher \\ William L. Robison
}

April 1994

Work performed under the auspices of the U.S. Department of Energy at Lawrence Livermore National Laboratory under contract W-7405-Eng-48.
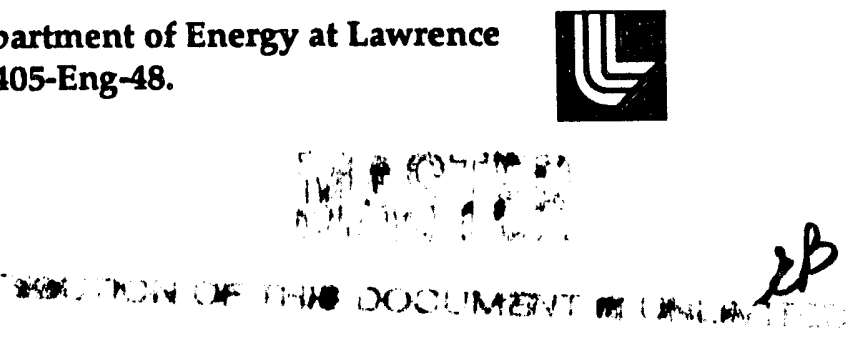


\section{Table of Contents}

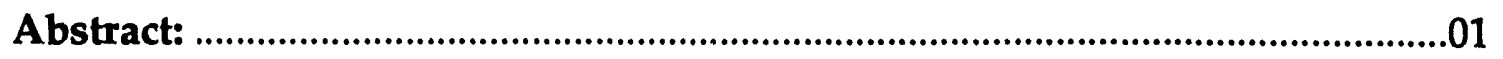

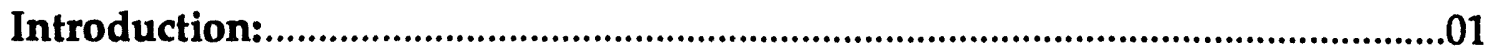

Methods and Results:

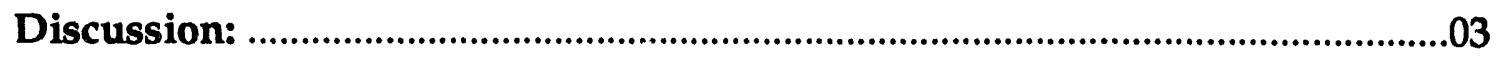

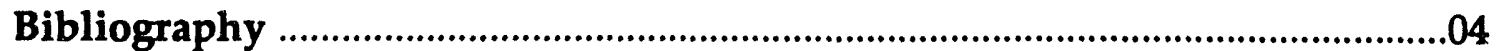




\begin{abstract}
:
The purpose of this project was to compile a bibliography of references containing environmental transuranic radionuclide data. Our intent was to identify those parameters affecting transuranic radionuclide transport that may be generic and those that may be dependent on chemical form and/or environmental conditions (i.e. site specific). An understanding of the unique characteristics and similarities between source terms and environmental conditions relative to transuranic radionuclide transport and cycling will provide the ability to assess and predict the long term impact on man and the environment. An additional goal of our literature review, was to extract the ranges of environmental transuranic radionuclide data from the identified references for inclusion in a data base. Related to source term, these ranges of data can be used to calculate the dose to man from the radionuclides, and to perform uncertainty analyses on these dose assessments.
\end{abstract}

In an attempt to gather relevant information about the transuranic radionuclides in a variety of environments, we conducted an extensive literature search. In our literature search we identified over 5700 potential written sources of information for review. In addition, we have identified many references which were not found through the literature searches, but which were known to contain useful data. A total of approximately 2600 documents were determined to contain information which would be useful for an in depth study of radionuclides in different environments. The journal articles, books, reports and other documents were reviewed to obtain the source term of the radionuclides studied. Most references containing laboratory study data were not included in our databases. Although these may contain valuable data, we were trying to compile references with information on the behavior of the transuranics in the specific environment being studied.

On the basis of our reviews, we have arbitrarily outlined five general source terms. These are fallout, fuel cycle waste, accidents, disposal sites and resuspension. Resuspension of the transuranic radionuclides is an unique source term, in that the radionuclides can originate from any of the other source terms. If these transuranic radionuclides become resuspended into the air, they then become important as a source of inhaled radionuclides. This bibliography is a compilation of the references containing studies of plutonium and americium in the environment as a result of resuspension.

\title{
Introduction:
}

The issue of transuranic radionuclides in the environment has been the subject of extensive research. For approximately five decades, plutonium and americium have been dispersed into the environment, resulting in widespread low level contamination of soil, water, plants and animals. To compare the transport, uptake, cycling and resuspension of plutonium and americium from various 
source terms around the world, it was necessary to summarize information from studies of these radionuclides in different environments. Some logical method of categorizing the source of the transuranic radionuclides had to be devised to use the data from the studies in a predictive manner. Our first task was to identify the source terms which we considered to be of primary importance.

The resuspension of transuranic radionuclides into the environment is an important and unique source term. The study of how these radionuclides become resuspended into the atmosphere, and therefore available for inhalation, is extremely important. Evaluating the behavior of the resuspended transuranic radionuclides in aquatic, terrestrial and atmospheric ecosystems has been the focus of many studies.

The data concerning resuspension includes analyses of different isotopes in different environmental media in different locations. Using these data, we hope to gain a better understanding of the transuranic radionuclide transport, cycling, uptake, and resuspension to evaluate site specific and generic applications.

\section{Methods and Results:}

We began by searching several large on-line databases using keywords which we had identified as relevant to transuranic radionuclide transport, uptake and cycling in the environment. These searches were performed from June through September 1992.

The Energy Data Base was the first on-line database we searched. Using our original keyword strategy, the original number of identified items was only 869 . On the basis of each abstract provided with the search, only 516 seemed to contain the kind of information relevant to our goals. We adjusted our keyword list by both expanding some areas, and narrowing the focus in others. A second search of the Energy Data Base produced an additional 4258 titles. About 1700 of these items were determined to be of interest.

Next, we expanded our search to the Chem Abstracts Data Base. This search yielded 969 items. Some of these had already been identified through the Energy Data Base searches. In addition to the references identified in our on-line searches, we were already in possession of several references known to contain useful data. A final search was performed with the intent of yielding these known references. This assured us that our keyword list was in fact producing the intended result.

After the final search was completed, we began to obtain all of the identified references. As these were obtained, the reference list at the end of each document was checked for additional references that had not been previously identified. This resulted in further titles being added to our bibliographic database. 
To produce our bibliography and environmental source term databases, we have used two commercially available software packages. ProCite ver. 2.0 for the Macintosh was used to produce the bibliography. The source term database was produced using dBase IV, ver. 1.5 on an IBM PS/2. The two different software packages were cross referenced to each other using a common field. The dBase IV database was used to keep track of the information extracted from the references. This allowed us to sort the references using a variety of criteria.

\section{Discussion:}

This bibliography is an attempt to provide a resource for information on the behavior of resuspended transuranic radionuclides. Our final on-line database search was in September 1992 There may be additional references of interest in these on-line databases which have been added since that time. References identified by other methods have been included through July 1993. 


\section{Blbllography}

Anspaugh, L.R., P.L. Phelps, N.C. Kennedy and H.G. Booth, Wind-Driven Redistribution of Surface-Deposited Radioactivity, UCRL-74392, (1973).

Anspaugh, L.R., "Appendix A, Resuspension Element Status Report: The Use of NTS Data and Experience to Predict Air Concentrations of Plutonium Due to Resuspension on the Enewetak Atoll," The Dynamics of Plutonium in Desert Environments. Nevada Applied Ecology Group Progress Report as of January 1974. P.B. Dunway and M.G. White, Eds., NVO-142, (1974).

Anspaugh, L.R. and P.L. Phelps, "Results and Data Analysis: Resuspension Element Status Report," The Dynamics of Plutonium in Desert Environments. Nevada Applied Ecology Group Progress Report as of January 1974.. P.B. Dunaway and M.G. White, Eds., NVO-142, (1974).

Anspaugh, L.R., J.H. Shinn and D.W. Wilson, "Evaluation of the Resuspension Pathway toward Protective Guidelines for Soil Contamination with Radioactivity," Popul. Dose Eval. Stand. Man His Environ., Proc. Semin, pp. 513-24, (1974).

Anspaugh, L.R., P.L. Phelps, N.C. Kennedy, H.G. Booth and R.W. Goluba, Resuspension of Plutonium: A Progress Report, UCRL-75484, (19 Feb 1974).

Anspaugh, L.R., J.H. Shinn and P.L. Phelps, Resuspension and Redistribution of Plutonium in Soils, UCRL-76419, (1975).

Anspaugh, L.R., J.H. Shinn, P.L. Phelps, and N.C. Kennedy, "Resuspension and redistribution of plutonium in soils," Health Phys., Vol. 29, 571-582, (Oct. 1975.)

Anspaugh, L.R. and P.L. Phelps "Resuspension Element Status Report, May 1975," Studies of Environmental Plutonium and Other Transuranics in Desert Ecosystems. Nevada Applied Ecology Group Progress Report (Workshop Session May 1975) NVO-159, (1976).

Anspaugh, L.R., P.L. Phelps, N.C. Kennedy, J.H. Shinn and J.M. Reichman, "Experimental Studies on the Resuspension of Plutonium from Aged Solurces at the Nevada Test Site," Atmosphere-Surface Exchange of Particulate ará Gaseous Pollutants (1974), CONF-740921, (1976).

Australian Atomic Energy Commission Research Establishment, Options for Clean-Up of the Maralinga Test Site., AAEC/DR20, (June 1985).

Bennett, B.G., "Transuranic Element Pathways to Man. (239 Pu, 240Pu.)," Transuranium Nuclides in the Environment, pp. 367-382, (1976). 
Bulman, R.A., Concentration of Actinides in the Food Chain, NRPB-R44, (1976).

Cambray, R.S. and J.D. Eakins, "Pu, ${ }^{241} \mathrm{Am}$ and ${ }^{137} \mathrm{Cs}$ in soil in West Cumbria and a maritime effect," Nature (London) , Vol. 300, 46-48, (4 Nov 1982).

Cataldo, D.A. and B.E. Vaughan, "Retention, Absorption, and Translocation of Follar Contaminants," Transuranics in Natural Environments. A symposium at Gatlingburg October 1976, NVO-178, (1976).

Cataldo, D.A... and B.E. Vaughan, "Interaction of Airborne Plutonium with Plant Foliage," Transuranic Elem. Environ., DOE/TIC-22800, (1980).

Condit, R.H., Plutonium Dispersal in Fires: Summary of what is Known, UCRL-ID114164, (July 1993).

Cooper, M.B., J.C. Duggleby, L.H. Kotler and K.N. Wise, Residual Radioactive Contamination of the Maralinga Range from Nuclear Weapons Tests Conducted in 1956 and 1957, ARL/TR-005, (Dec 1978).

Cooper, B.M., K.B. Marchall, K.A. Thomas and B.L. Tracy, "Artificial Resuspension Studies. Chapter 3," Inhalation Hazard Assessment at Maralinga and Emu. G.A. Williams Ed., ARL-TR-087, (May 1990).

Fowler, S.W., S. Ballestra, J. LaRosa and R. Fukai, "Vertical transport of particulate-associated plutonium and americium in the upper water column of the Northeast Pacific," Deep-Sea Res., Part A , Vol. 30, 1221-1233, (1983).

Garger, Y.K., V.P. Gavrilov and G.P. Zhukov, "Estimation of the Secondary Contamination of Resuspension within the $30 \mathrm{~km}$ Zone of Cherobyl NPP and its Comparison with Measured Data," Precipitation Scavenging and AtmosphereSurface Exchange. The Summers Volume: Applications and Appraisals, Proceedings of the Fifth International Conference on Precipitation Scavenging and Atmosphere-Surface Exchange Processes, Richland, Washington, 15-19 July, 1991. S.E. Schwartz and W.G. Slinn, Coordinators, Vol. 3, pp. 1595-1603 (1993).

Garland, J.A., Resuspension of Particulate Matter from Grass and Soil, AERE-R-9452, (May 1979).

Garland, J.A. and K. Playford, "Resuspension Following the Chernobyl Accident," Precipitation Scavenging and Atmosphere-Surface Exchange. The Summers Volume: Applications and Appraisals, Proceedings of the Fifth International Conference on Precipitation Scavenging and AtmosphereSurface Exchange Processes, Richland, Washington, 15-19 July, 1991. S.E. Schwarts and W.G. Slinn, Coordinators, Vol. 3, pp. 1605-1614 (1993). 
Gilbert, R.O., D.W. Engel, D.D. Smith, J.H. Shinn, L.R. Anspaugh and G.R. Eisele, "Transfer of aged Pu to cattle grazing on a contaminated environment," Health Phys., Vol. 54, 323-335, (Mar 1988).

Gilbert, R.O., J.H. Shinn, E.H. Essington, T. Tamura, E.M. Romney, K.S. Moor and T.P. O'Farrell, "Radionuclide transport from soil to air, native vegetation, kangaroo rats and grazing cattle on the Nevada test site," Health Phys., Vol. 55, 869-887, (Dec 1988).

Golchert, N.W. and J. Sedlet, "Resuspension Studies on Fallout Level Plutonium," Selected Environmental Plutonium Research Reports of the NEAG, NOV-192, Vol. 2, (1978).

Hanson, W.C., "Ecological considerations of the behavior of plutonium in the environment," Health Phys ., Vol. 28, 529-537, (1975).

Hartmann, G. and K. Baechmann, "Plutonium and other trace elements in-on plants," J. Environ Radioact , Vol. 8, 21-36, (1988).

Hartmann, G., C. Thom and K. Baechmann, "Sources for Pu in near surface air," Health Phys., Vol. 56, 55-69, (Jan 1989).

Healy, J.W., "A Review of Resuspension Models," Transuranics in Natural Environments, NVO-178, (1976).

Hirose, K. and Y. Sugimura, "Plutonium in the surface air in Japan," Health Phys., Vol. 46, 1281-1285, (Jun 1984).

Hodgin, C.R., "Mechanical Resuspension of Plutonium-239 from Unpaved Roads," Precip. Scavenging, Dry Deposition, Resuspension, 4th Proc. Int. Conf. 1982. H.R. Pruppacher, R.G. Semonin and W.G.N. Slinn, Eds., Vol. 2 pp. 1175-1184, (1983).

Horrill, A.D. and S. Mudge, "The influence of grassland management on the radionuclide inventory of soils in West Cumbria, UK," Journal of Environmental Radioactivity, Vol. 12, 143-165, (1990).

Iranzo, E.S., Inhalation Risks to People Living Near A Contaminated Area, Second International Congress of the International Radiation Protection Association, Brighten, England, 3-8 May 1970, (1970).

Iranzo, Gonzales E. and S. Salvador Ruiz, Doses from Potential Inhalation by People Living Near Plutonium Contaminated Areas, ORNL-TR-5060, (Sep 1983).

Iranzo, E., S. Salvador and C.E. Iranzo, "Air concentrations of ${ }^{239} \mathrm{Pu}$ and ${ }^{240} \mathrm{Pu}$ and potential radiation doses to persons living near Pu-contaminated areas in Palomares, Spain," Health Phys., 453-461, (Apr 1987). 
Krey, P., E. Hardy, H. Volchok, L. Toonkel, R. Knuth, M. Coppes and T. Tamura, Plutonium and Americium Contamination in Rocky Flats Soil, 1973, HASL-304, (Mar 1976).

Langer, G., Activity, Size, and Flux of Resuspended Particles from Rocky Flats Soil, RFP-3469, (1982).

Langer, G., Wind Resuspension of Trace Amounts of Plutonium Particles from Soil in A Semi-Arid Climate, RFP-3633, (1984).

Langer, G., Dust Transport: Wind Blown and Mechanical Resuspension, July 1983 to December 1984, RFP-3914, (20 Sep 1986).

Linsley, G.S., Resuspension of the Transuranium Elements - A Review of Existing Data, National Radiological Protection Board, Harwell, Didcot, Oxion, UKNRPB-R75, (1978).

Little, C.A., Plutonium in a grassland ecosystem (238Pu, $\left.{ }^{239} \mathrm{Pu}\right)$, Colorado State Univ., Fort Collins, CO, (1976).

McHugh, J.O. and J.A. Hetherington, "Airborne radioactivity on the Scottish Solway coast," J. Environ. Radioact., Vol. 5, (1987).

Michels, D.E., Plutonium Resuspension from Soil. How Measurable, RFP-1927, (1972).

Pattenden, N.J., R.S. Cambray, K. Playford, J.D. Eakins and E.M.R. Fisher, "Atmospheric Measurements on Radionuclides Previously Discharged to Sea," International Symposium on the Impacts of Radionuclide Releases into the Marine Environment, Vienna, 6-10 October 1980, (1981).

Phelps, P.L. and L.R. Anspaugh, Resuspension Element Status Report. The Radioecology of Plutonium and other Transuranics in Desert Environments. Nevada Applied Ecology Group Progress Report, NOV-153, (1975).

Phelps, P.L. and L.R. Anspaugh, "Development of Specialized Instruments and Techniques for Resuspension Studies," Transuranics in Natural Environments, NVO-178, (1976).

Porch, W.M., G.D. Greenly and C.S. Mitchell, Update and inclusion of resuspension model codes, UCID-20071, (1983).

Romney, E.M., "Studies of Environmental Plutonium and Other Transuranics in Desert Ecosystems," NAEG Plutonium Program Vegetation Studies Status Report, May 1975.. Nevada Applied Ecology Group Progress Report (workshop session May, 1975). M.G. White and P.B. Dunaway, Eds., NVO-159, (1976).

Romney, E.M. and A. Wallace, Plutonium Contamination of Vegetation in Dusty Field Environments, NVO-178, (1977). 
Sehmel, G.A., Airborne ${ }^{238} \mathrm{Pu}$ and ${ }^{239} \mathrm{Pu}$ Associated with the Larger than "Respirable" Resuspended Particles at Rocky Flats during July 1973, BNWL-2119, (Sep 1976).

Sehmel, G.A., Radioactive Particle Resuspension Research Experiments on the Hanford Reservation, BNWL-2081, (Feb 1977).

Sehmel, G.A., "Plutonium and Tracer Particle Resuspension: An Overview of Selected Battelle-Northwest Experiments (239 Pu, 137Cs)," Transuranics in Natural Environments. M.G. White and P.B. Dunaway, Eds., NVO-178, (Jun 1977).

Sehmel, G.A., Transuranic and Tracer Simulant Resuspension $\left({ }^{238} \mathrm{Pu},{ }^{239} \mathrm{Pu},{ }^{240} \mathrm{Pu}\right)$, BNWL-SA-6236, (Jul 1977).

Sehmel, G.A., Plutonium Concentrations in Airborne Soil at Rocky Flats and Hanford Determined during Resuspension Experiments, PNL-SA-6720, (Jan 1978).

Sehmel, G.A., "Airborne Plutonium-239 Transport Measured from the 125-m Hanford Meterological Tower," Pacific Northwest Laboratory Annual Report for 1977 to the DOE Assistant Secretary for Environment. Part 3, Atmospheric Sciences. C.L. Simpson. Ed., PNL-2500(Pt.3), (Feb 1978).

Sehmel, G.A., "Offsite Plutonium Resuspension Near Hanford. (239 Pu.)," Pacific Northwest Laboratory Annual Report for 1977 to the DOE Assistant Secretary for Environment. Part 3, Atmospheric Sciences. C.L. Simpson, Ed., PNL-2500(Pt.3), (Feb 1978).

Sehmel, G.A., "Airborne Plutonium-239 and Americium-241 Transport Measured from the 125-M Hanford Meteorological Tower," Selected Environmental Plutonium Research Reports of the NAEG, NVO-19, Vol. 2, (1978).

Sehmel, G.A., "Plutonium Resuspension $\left({ }^{239} \mathrm{Pu},{ }^{240} \mathrm{Pu}\right), "$ Pacific Northwest Laboratory Annual Report for 1978 to the DOE Assistant Secretary for Environment. Part 3, Atmospheric Sciences. C.L. Simpson, Ed., PNL-2850(Pt.3), (Feb 1979).

Sehmel, G.A., "Characteristics of Airborne Plutonium Resuspended from NearBackground Aged Surface-Sources," Precip. Scavenging, Dry Deposition, Resuspension, 4th Proc. Int. Conference. H.R. Pruppacher, R.C. Semonin and W.G.N. Slinn, Eds., Vol. 2, pp. 1145-59, (1983).

Shinn, J.H., N.C. Kennedy, J.S. Koval, B.R. Clegg and W.M. Porch, "Observations of Dust Flux in the Surface Boundary Layer for Steady and Nonsteady Cases," Proceedings Symposium Atmosphere Surface Exchange of Particulate and Gaseous Pollutants, Richland, WA, September 3-6, 1974, pp. 625-, (1974). 
Shinn, J.H., Estimation of Aerosol Plutonium Transport by the Dust-Flux Method: A Perspective on Application of Detailed Data, UCRL-78907, (10 Dec 1976).

Shinn, J.H. and D.N. Homan, Plutonium-Aerosol Emission Rates and Human Pulmonary Deposition Calculations for Nuclear Site 201, Nevada Test Site, UCRL-53301, (1982).

Shinn, J.H., D.N. Homah and D.D. Gay, Plutonium Aerosol Fluxes and Pulomnary Exposure Rates during Resuspension from Bare Soils Near A Chemical Separation Facility, UCRL-87676, (Nov 1982).

Shinn, J.H. and D.N. Homan, "Monitored particle resuspension rates and inhalation exposure during a cleanup and treatment test of plutonium contaminated soil in Nevada, USA," Health Phys (Abstract), Vol. 47, 200-, (1984).

Shinn, J.H., D.N. Homan and C.B. Hofman, A Summary of Plutonium Aerosol Studies: Resuspension at the Nevada Test Site, UCRL-90746, (1986).

Shinn, J.H., D.N. Homan and W.L. Robison, Resuspension Studies at Bikini Atoll (Pulmonary Exposure from Dust-Borne Plutonium Aerosols), UCID-18538, Rev. 1, (Aug 1989).

Shinn, J.H., E.H. Essington, F.L.J. Miller, T.P. O'Farrell, J.A. Orcutt, E.M. Romney, J.W. Shugart and E.R. Sorom, "Results of a cleanup and treatment test at the Nevada, USA, Test Site: Evaluation of vacuum removal of plutonium contaminated soil," Health Physics , Vol. 57, 771-780, (1989).

Shinn, J.H., Enhancement Factors for Resuspended Aerosol Radioactivity: Effects of Topsoil Disturbance, UCRL-JC-105257, (Nov 1991). See also: Precipitation Scavenging and Atmosphere-Surface Eschange, Hemisphere Publishing, Vol. 3, 1183-1193, (1992).

Smith, L.C., HSEE Application Technology Semiannual Progress Report July through December 1985, RFP-4036, (May 1, 1987).

Talmage, S.S. and B.D. Chilton, Cleanup Procedures at the Nevada Test Site and at Other Radioactively Contaminated Sites Including Representative Costs of Cleanup and Treatment of Contaminated Areas, ORNL-6317, (1987). 

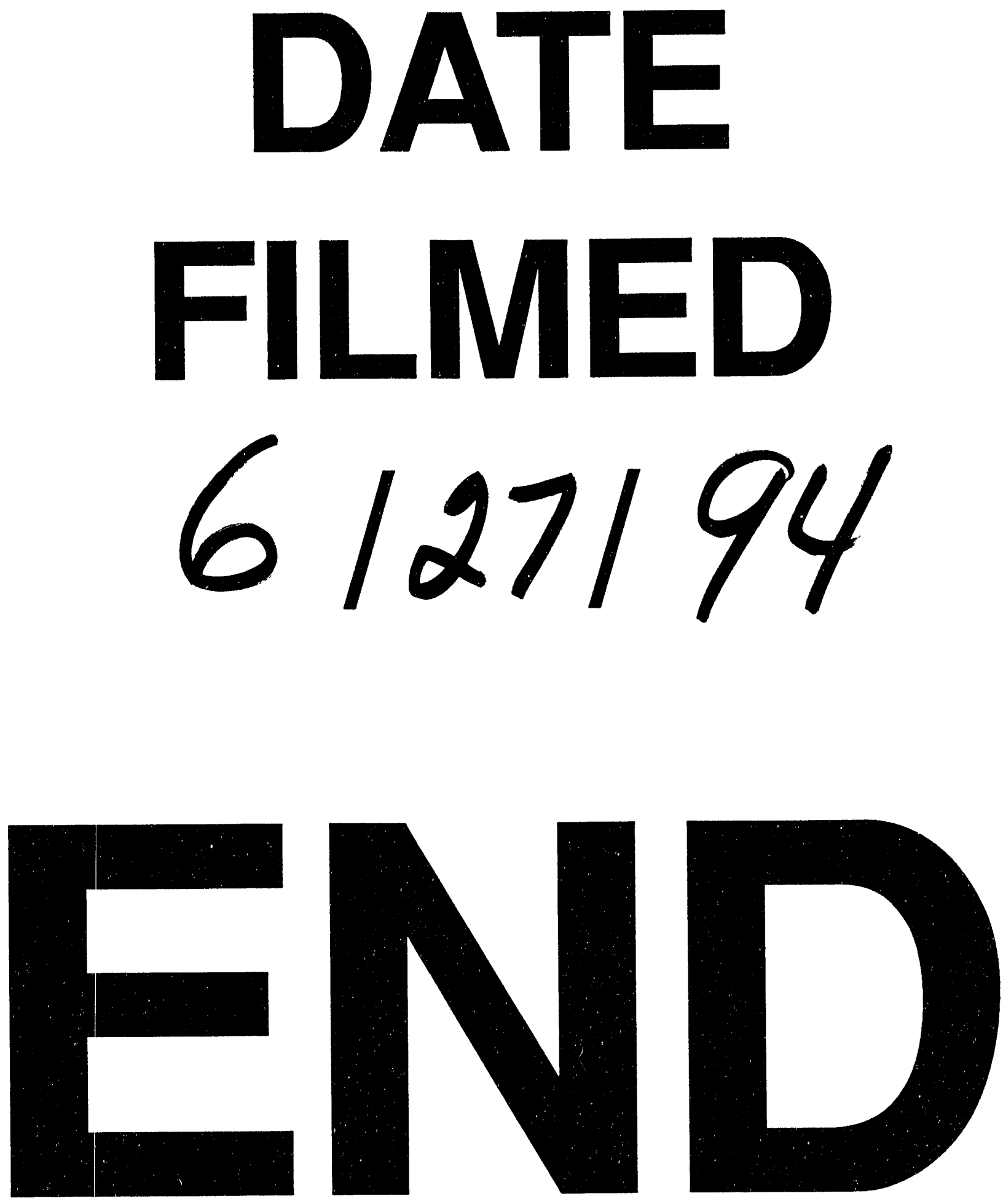
